\title{
POLA PEMBINAAN MUALLAF DI KOTA JAYAPURA
}

\author{
Development Pattern of Converts in Jayapura City \\ Sahara* \\ *Balai Litbang Agama Makassar \\ Jl. A. P. Pettarani No. 72 Makassar \\ Email: barack filsafat@vahoo.co.id
}

Koreksi naskah I tanggal 17 Juni 2012. Koreksi naskah II tanggal 25 Juni 2012. Finalisasi Naskah 9 Oktober 2012

\begin{abstract}
Abstrak
Penelitian ini adalah penelitian tentang pola pembinaan muallafdi Jayapura, yang berfokus pada tiga masalahpeneltian, yaitu bagaimanapembinaan muallaf, problem pembinaan, dan dukungan kementerian agama. Penelitian ini ditujukan untuk mengetahui pola pembinaan muallaf menginventarisir problem pembinaan dan melihat keterlibatan dan dukungan kementerian agama terhadap pembinaan muallaf. Penelitian ini menggunakan metode kualitatif dengan analisis data deskriptif analitis. Pembinaan muallaf di Jayapura dilakukan secara swadaya oleh beberapa individu dai dan beberapa resourch sosial, baik yayasan, majelis taklim, maupun ormas. Isu Islamisasi, benturan kultural, kendala geografis, kendala finansial, dan minimnya jumlahpenyuluh agama PNS menjadi kendala dalampembinaan muallaf. Jajaran kementerian agama baik kota/kabupaten dan provinsi cukup terlibat dalam pembinaan muallaf, meski keterlibatan tersebut lebih bersifat personal dan bukan institusional.
\end{abstract}

Kata Kunci: Pembinaan Muallaf Muslim Papua, dan kementerian agama

\begin{abstract}
This study is about the development pattern of convert in Jayapura, which focuses on three other research issues, namely how the coaching of the convert, coaching problems, and support the ministry of religion. This study aimed to determine the pattern of convert coaching, coaching inventory problem and see the involvement and support of religious ministries to the coaching of converts. This study used qualitative methods of data analysis descriptive analysis. Coaching converts in Jayapura conducted independently by several individuals like proselytizer and some social resourch, like foundation, Majelis Taklim, and community organizations. The issue of Islamization, cultural clash, geographic constraints, financial constraints, and inadequate number of civil servants religion counselors, to be an obstacle in the development to the converts. The line of ministries of religious both in town or regency and provincial quite involved in coaching convert, although involvement is more personal and not institutional.
\end{abstract}

Keywords: coaching convert, muslim of Papua and religious ministry

\section{PENDAHULUAN}

I de penelitian tentang pembinaan muallaf merupakan kelanjutan dari penelitian Balai Litbang Agama Makassar pada tahun 2010 tentang dakwah di daerah terpencil. Dari hasil penelitian tersebut ditemukan fakta bahwa problematika dakwah di beberapa daerah yang sasarannya adalah para muallaf masih belum berjalan secara maksimal. Muallaf yang nota bene adalah orang yang umumnya masih minim pengetahuan dan pengamalan ajaran islam, sehingga masih butuh pembinaan, pada kenyataanna belum optimal dibina. Sehingga, terdapat kasus muallaf yang belum maksimal melaksanakan ajaran Islam, belum mampu membaca kitab suci Alquran, dan lain-lain.
Bagaimana meletakkan kajian pembinaan muallaf ini dengan kebijakan pemerintah? Secara eksplisit, muallaf tidak menjadi sasaran khusus dalam kebijakan pemerintah. Ini dapat dimaklumi mengingat negara Indonesia tidak berbasis agama tertentu. Kajian pembinaan muallaf dapat diletakkan dalam renstra kementerian agama pada poin; peningkatan kualitas kehidupan beragama, dan peningkatan kerukunan umat beragama.

Provinsi Papua, khususnya kota dan kabupaten Jayapura merupakan daerah dengan jumlah muallaf yang cukup besar. Ratusan orang setiap tahunnya menjadi muallaf dengan berbagai motif. Kondisi sosio kultural masyarakat Papua yang diidentikkan dengan 
Kristen, membuat fenomena konversi agama menjadi muslim menjadi isu yang sensitif dan akan sangat rentan menjadi isu Islamisasi. Hal ini tentu saja bisa menjadi potensi laten konflik antar umat beragama (Islam dan Kristen) di Papua. Ditambah lagi panasnya situasi politik Papua terkait dengan gerakan separasi Papua Merdeka. Di sebagian masyarakat Papua, muncul stigma tentang Islam yang diidentikkan dengan NKRI, Islam identik dengan pendatang. Walaupun masyarakat muslim asli Papua mengorganisasi diri dalam bingkai ke-Papua-an seperti Majelis Muslim Papua (MMP) dan Forum Komunikasi Muslim Pegunungan Tengah (FKMPT) Papua,' beum sepenuhnya mampu menghapus stigma tersebut. Dengan demikian penelitian tentang pembinaan muallaf di Papua, khususnya di kota Jayapura sebagai sampel menjadi penting khususnya jika dikaitkan dengan 2 poin penting dalam renstra kementerian agama yang telah disebutkan.

Penelitian ini berfokus untuk menjawab tiga masalah, yaitu: 1. Bagaimana pola pembinaan muallaf di Jayapura? 2. Apa problem pembinaan yang dialami? 3. Bagaimana keterlibatan dan dukungan kementerian agama dalam pembinaan muallaf?

Penelitian ini menjadi penting untuk mengetahui pola pembinaan muallaf yang selama ini dilakukan, menginventarisir problematika yang dihadapi dalam pembinaan, serta melihat keterlibatan dan dukungan kementerian agama dalam pembinaan muallaf.

Secara konseptual, yang dimaksud muallaf. Yang dimaksud muallaf dalam penelitian ini adalah semua orang yang beralih agama dari agama tertentu (termasuk agama lokal) ke dalam Islam. Sedanngkan yang dimaksud pembinaan adalah semua bentuk pemenuhan kebutuhan spritual dan lainnya yang bertujuan untuk meningkatkan kualitas keberagamaan seorang muallaf, baik yang dilakukan oleh tokoh agama, organisasi keagamaan, lembaga keagamaan, lembaga pendidikan agama, dan kementerian agama.

\section{Teori Pembinaan Keagamaan}

Pembinaan adalah kegiatan terorganisir yang dilakukan oleh seseorang atau lembaga untuk membantu kelompok tertentu (yang dianggap memiliki kelemahan tertentu) mendapatkan pengetahuan tentang obyek tertentu. Capaian utamanya adalah terjadinya perubahan sikap dan orientasi dari kelompon yang dibina itu. Merujuk pada Berger dan Luckmann pembinaan adalah habitualisasi atau proses pembiasaan sebagai tindakan yang berulang yang pada akhirnya menjadi suatu pola dan dipahami oleh pelakunya sebagai pola yang dimaksud. ${ }^{2}$

Dalam konteks pembinaan keagamaan muallaf, tema pembinaan berkaitan dengan penguatan spritual para muallaf untuk lebih memahami keislaman yang berarti penguatan keimanannya yang pada akhirnya memunculkan kepercayaan dalam dirinya untuk beraktualisasi sebagai manusia dengan identitas baru. Dengan demikian, pembinaan yang dimaksud adalah proses mempelajari norma, nilai, sikap, dan prilaku baru yang sepadan dengan situasi baru (kemuallafan) yang mereka hadapi dalam kehidupan.

Model pembinaan ada dua, pembinaan struktural dan pembinaan non-struktural. Pembinaan struktural adalah model pembinaan yang secara terstruktur yang biasanya dilakukan oleh lembaga atau organisasi tertentu dengan capaian indikator sesuai dengan kepentingan lembaga dan organisasi bersangkutan. Sedangkan pembinaan non struktural adalah model pembinaan yang dilakukan secara sporadis, tidak memiliki sistem yang jelas. Model ini biasanya dilakukan oleh individu yang memiliki semangat pengabdian.

\section{Teori Konversi Agama}

Teori konversi agama (religious conversion) yang muncul pada era tahun 80-an hingga akhir abad 20 M- ini dapat diartikan dengan peristiwa perpindahan agama ataupun masuk agama. Secara etimologi, konversi berasal dari kata latin conversio yang berarti taubat, pindah, dan atau berubah (agama). Dalam Bahasa Inggris, conversion mengandung pengertian berubah dari suatu keadaan, atau dari suatu agama ke agama lain \{change from one state, orfrom one religion, to another). Berdasarkan arti kata-kata tersebut dapat disimpulkan bahwa konversi agama mengandung pengertian: bertaubat, berubah agama, berbalik pendirian (berlawanan arah) terhadap ajaran agama yang lama atau masuk ke dalam ajaran agama yang baru yang tentunya lebih baik, lebih

\footnotetext{
' Sebelumnya bernama Forum Komunikasi jayawijaya (FKMJ) merupakan organisasi yang menghimpun muslim asli Papua yang berasal dari wilayah disekitar pegunugan Jayawijaya dan sekitarnya.

${ }^{2}$ Peter L. Berger dan Thomas Luckmann, Tafsir Sosial alas Kenyataan, Jakarta. LP3ES, 2012, h. 72.

${ }^{3}$ Lihat Dims\&r,Pengantar Sosiologi Pendidikan, 2011, Jakarta: Prenada Media Kencana, h. 67.
} 
menentramkan dan lebih menenangkan dari ajaran agama yang lama (menurut subyek konversi). Heirich mengatakan bahwa konversi agama adalah suatu tindakan masuk atau berpindah kepada suatu sistem kepercayaan atau perilaku yang berlawanan dengan kepercayaan sebelumnya. ${ }^{4}$

Konversi agama, kendatipun merupakan suatu hal yang manusiawi dan wajar, akan tetapi memiliki latar belakang dan tahapan-tahapan proses yang dialami oleh subjek konversi agama. Menurut Jalaluddin ada 3 alasan seseorang untuk konversi agama, yaitu sebab hidayah (pengalaman spiritual), alasan belajar (pendekatan intelektual, dan alasan sosial (termasuk motif perkawinan diantaranya). ${ }^{5}$

Penelitian menggunakan metode kualitatif. Dalam penelitian dengan metode ini, data-data dikumpulkan dengan cara:

a. Wawancara yaitu menggali data dengan melakukan wawancara dengan orang-orang yang terkait dengan penelitian. Tema wawancara seputar isu pembinaan muallaf khususnya kepada individu, lembaga, dan ormas yang melakukan pembinaan. Sedangkan untuk para muallaf wawancara seputar pengalaman masuk Islam, pengalaman ikut dalam pembinaan, dan ekspektasi sebagai muallaf.

b. Observasi. Penelitian ini juga dilakukan dengan melakukan pengamatan di lokasi penelitian mengenai pembinaan muallaf.

c. Studi pustaka dan dokumen yang terkait dengan topik penelitian yang dilakukan.

Untuk menentukan informan, dilakukan dengan cara social mapping, artinya informan dipilih dari kalangan tertentu yang dianggap bisa merepresentasikan topik penelitian. Analisis data dilakukan dengan metode analisis deskriptif tapi kritis. Data dijelaskan dengan mengaitkan berbagai realitas yang memungkinkan pembinaan muallaf berlangsung dengan baik (atau tidak baik). Realitas yang dimaksud adalah realitas struktural seperti dukungan kementerian agama dan pemerintah lokal dalam mendukung pembinaan muallaf.

\section{PEMBAHASAN}

\section{Setting Lokasi Penelitian}

Kota Jayapura terbagi atas 5 distrik (kecamatan) dan 39 kelurahan, dengan persebaran penduduk yang tidak merata. Konsentrasi penduduk pada distrik Jayapura Utara dan Jayapura Selatan, serta distrik Abepura. Sedangkan dua distrik yang lain, yaitu distrik Muara Tami dan distrik Heeram memiliki populasi penduduk yang relatif kurang.

Mengenai jumlah penduduk, terjadi perbedaan antara data dari BPS Kota Jayapura dan data kependudukan dari Kementerian Agama. Pada tahun 2010 menurut BPS Kota Jayapura, penduduk Kota Jayapura berjumlah 256.705 jiwa dengan rincian 136.587 pria dan $120 \mathrm{~J} 18$ wanita. Jumlah ini meningkat dari tahun 2009, di mana pada saat itu, penduduk kota Jayapura berjumlah 242.225 jiwa dengan rincian 128.534 pria dan 113.691 wanita. Berdasarkan klasifikasi jumlah penduduk pria dan wanita di kota Jayapura dapat dilihat bahwa rasio gender di kota Jayapura adalah 53:47, maksudnya dari 100 penduduk kota Jayapura, maka 53 adalah pria dan 47 adalah wanita, atau jumlah pria lebih banyak dari jumlah wanita. Laju pertumbuhan penduduk di daerah ini termasuk tinggi, yaitu rata-rata $3,5 \%$ per tahun. Tingginya laju pertumbuhan penduduk ini disebabkan tingginya angka migrasi penduduk dari luar Jayapura masuk ke Jayapura.

Berbeda dengan data BPS Kota Jayapura, data kependudukan dari Kementerian Agama Kota Jayapura pada tahun 2009 berjumlah 255.937 jiwa, pada tahun 2010 berjumlah 263.010 jiwa, dan pada tahun 2011 meningkat lagi menjadi 265:640 jiwa. Distrik dengan penduduk terbanyak adalah distrik Jayapura Utara dengan jumlah penduduk berjumlah 82,540jiwa dan distrik dengan jumlah penduduk paling sedikit adalah distrik Muara Tami yang hanya berjumlah 20.417 jiwa. Dilihat dari jumlah penduduk dan luas wilayah, maka kota Jayapura memiliki tingkat kepadatan penduduk, yaitu 282,5 jiwa/Km2.

Dari 256.705 jiwa penduduk Jayapura berdasarkan data BPS Kota Jayapura tahun 2010, penduduk asli Papua berjumlah 89.587 jiwa atau 34,9\% dari total jumlah penduduk Jayapura. Dengan rincian

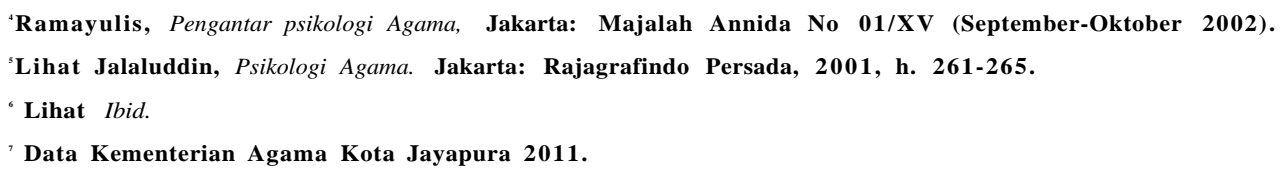


2.938 jiwa asli Papua Barat, 86.368 jiwa adalah asli Papua. Sisanya adalah penduduk pendatang yang berasal dari berbagai daerah di Indonesia, yang terbesar berasal dari Sulawesi Selatan, Maluku, dan Jawa. Sedangkan untuk keseluruhan penduduk aslli Papua yang bermukim di provinsi Papua adalah 2.151.592jiwa atau 76,87\% dari total jumlah penduduk provinsi Papua yang berjumlah 2.798.938 jiwa berdasarkan sensus penduduk pada tahun 2010 .

\section{Mozaik Keberagamaan di Jayapura}

Mayoritas penduduk Kota Jayapura adalah Kristen, yaitu 120.170 jiwa atau 45,24\% dari total penduduk, selanjutnya adalah Islam berjumlah 96,460 jiwa atau 36,31\%, penganut Katolik berjumlah 45.561 jiwa atau $17,15 \%$, sedangkan untuk penganut Hindu dan Buddha masing-masing 1.586 jiwa dan 1.863 jiwa atau $0,59 \%$ dan $0,71 \%$ dari total penduduk Kota Jayapura.

Adapun distribusi penduduk berdasarkan penganut agama pada setiap distrik di Kota Jayapura pada tahun 2011, adalah:

\begin{tabular}{|c|c|c|c|c|c|c|}
\hline \multirow{2}{*}{ No } & \multirow{2}{*}{$\begin{array}{c}\text { Nama } \\
\text { Distrik }\end{array}$} & \multicolumn{5}{|c|}{ Jumlah Umat Berasama } \\
\hline & & Kristen & Katolik & Islam & Hindu & Budha \\
\hline 1. & Muara tami & 11337 & 3.397 & 5.677 & - & 6 \\
\hline 2. & Abepura & 22.032 & 15.329 & 19.741 & 590 & 362 \\
\hline 3. & Heram & 14.182 & 5.849 & 9.428 & 263 & 89 \\
\hline 4. & $\begin{array}{l}\text { Jayapura } \\
\text { Selatan }\end{array}$ & 32.536 & 8.743 & 32.503 & 276 & 720 \\
\hline 5. & $\begin{array}{l}\text { Jayapura } \\
\text { Utara }\end{array}$ & 40.083 & 12.243 & 29.111 & 457 & 686 \\
\hline \multicolumn{2}{|c|}{ J u m I a h } & 120.170 & 45.561 & 96.460 & 1.586 & 1.863 \\
\hline
\end{tabular}

Sumber: Kantor Kementerian Agama Kota Jayapura 2011

Berdasarkan data BPS provinsi Papua, dari penduduk asli Papua yang bermukim di kota Jayapura yang berjumlah 89.587 jiwa, sebagian besar adalah penganut Kristen dengan jumlah 82.247 jiwa atau $91,8 \%$, penganut Katolik berjumlah 4,751 jiwa atau $5,30 \%$, sedangkan penduduk asli Papua yang menganut Islam yang bermukim di Kota Jayapura hanya berjumlah 2.558 jiwa atau hanya $2,9 \%$. Sedangkan dari total jumlah penduduk asli Papua yang bermukim di provinsi Papua pada tahun 2010 yang berjumlah 2.151.592 jiwa, 1.695.523 jiwa atau 78,8\% adalah penganut Kristen, penganut Katolik berjumlah 443.950 jiwa atau 20,63\%, sedangkan penduduk asli Papua yang menganut Islam hanya berjumlah 11.596 jiwa atau
0,54\% saja dari total jumlah penduduk asli Papua, dan terdapat 523 jiwa atau 0,03\% penduduk pribumi Papua yang tercatat masih menganut keyakinan animisme. ${ }^{8}$

\section{Perkembangan Islam di Kota Jayapura}

Di Pulau Papua, Islam telah masuk sekitar abad XVI Masehi (tiga abad lebih dulu dari amsuknya agama Kristen yang pertama kali menjejakkan misinya di tanah Papua pada tahun 1855. Namun, dakwah Islam tidak berkembang dan massif, tercatat hanya 3 daerah yang sempat terislamkan, yaitu Fak-fak Raja Ampat, dan Kaimana, dan kesemuanya berada di daerah Papua bagian Barat. Untuk wilayah Papua (provinsi Papua) sendiri, dakwah Islam sangatlah terlambat masuk, Islam baru dikenal dan memasuki wilayah ini pada abad 20 melalui para pendatang serta pejuang RI yang dibuang oleh Belanda di Boven Digul dan Merauke.'

Untuk Kota Jayapura, dapat dikatakan syiar Islam pertama kali pada tahun 1910, ketika Haji Abdul Majid, seorang pedagang dari Tidore melaksanakan pengajian Alquran dan membangun mesjid pertama di Jayapura. ${ }^{10}$ Populasi umat Islam kemudian meningkat dengan berdatangannya pendatang, khususnya pasca integrasi Papua ke NKRI pada tahun 1963. Gerak dakwah Islam mulai menggeliat dengan berdirianya dua ormas Islam di Jayapura, yaitu Muhammadiyah pada tahun 1966 yang diketuai oleh H Ismail Bauw danNU pada tahun 1965 dengan ketua pertamanya Abdullah Killian, lalu berdiri YAPIS (Yayasan pendidikan islam) pada Desember 1968, Yayasan Pondok Karya Pembangunan (YPKP) pada tahun 1975, serta Hidayatullah di tahun 1990. Kelompok muslim,lokal juga mengorganisir diri dengan mendirikan Majelis Muslim Papua (MMP) yang didirkan pada 10 April 2007. Terkhusus untuk muslim asli Papua yang berasal dari wilayah Pegunungan Tengah (pegunungan Jayawijaya) pada tanggal 3 Maret 2003 membentuk Forum Komunikasi Muslim Jayawijaya (FKMJ) yang kemudian berubah nama menjadi Forum Komunikasi Muslim Pegunungan Tengah (FKMPT) pada Desember $2010 .^{11}$

Penyumbang terbesar populasi umat Islam di Jayapura yang berjumlah 96,460 jiwa atau 36,31\%,

\footnotetext{
" BPS Provinsi Papua, Papua dalam Angka 2011.

'Lihat Tony Victor Wanggai, Rekonslmksi Sejarah Umat Islam di Tanah Papua, Jakarta: Badan Litbang dan Diklat Kementerian Agama, 2009.

${ }^{10}$ Yayasan Pendidikan Islam (Yapis), Sejarah Pendidikan islam Yapis Irian Jaya, JayapuraL Yapis, 1999, h. 47.

${ }^{11}$ Lihat Tony Victor Wangga, op. cit., h. 154-159.
} 
dari total penduduk Jayapura adalah pendatang dari Jawa, Sulawesi, dan Maluku, hanya 2.558 jiwa saja atau hanya $2,65 \%$ dari populasi umat Islam Jayapura yang merupakan muslim asli Papua, itu pun sebagian besar adalah penduduk asli Papua yang berasal dari Fak-fak, Kaimana, dan Raja Ampat yang nota bene adalah mayoriats Islam. Muslim asli Papua (provinsi Papua) yang bermukim di Jayapura sebagian berasal dari muslim Pegunungan Tengah, khsusunya yang berasal dari daerah Walesi, Wamena yang jumlahnya sekitar 200-an orang, serta person-person etnik Papua yang mendapatkan hidayah dan memeluk Islam.

Secara sosio-kutural dan politk, Islam di tanah Papua, dan Jayapura khususnya menghadapi tantangan yang luar biasa. Islam oleh sebagian besar masyarakat asli Papua diidentikkan dengan pendatang dan oleh beberapa kalangan dari kelompok separatis OPM, Islam sering dikaitkan dengan NKRI. Perasaan terdiskriminasi dari masyarakat muslim asli Papua tampak dari pernyataan beberapa informan yang peneliti temui, bahwa muslim Papua mengalami diskriminasi dua kali, sebagai orang Papua mengalami diskriminasi dari NKRI, dan sebagai muslim terdiskriminasi oleh sesama warga asli papua. ${ }^{12}$ Tentu saja hal ini menjadi tantangan besar bagi perkembangan dan eksistensi Islam di tanah papua, khususnya muslim asli Papua.

\section{Pemetaan Muallaf di Jayapura}

Menurut data Kasi Urais dan Haji Kemenag Kota Jayapura, terdapat 162 orang muallaf sepanjangtahun 2011 yang terdiri atas 108 wanita dan 54 pria, ${ }^{13}$ data lain yang peneliti dapatkan di KUA Jayapura Selatan, antara tahun 2008 hingga Mei 2012 terdapat 132 orang yang diislamkan di KUA tersebut. Yayasan alMuhtadin di Sentani, sejak berdiri tahun 2000 telah melakukan pengislaman dan pembinaan sebanyak 297 muallaf, sesuai dengan data base yang tersimpan di yayasan tersebut.

Dapat dikatakan kebanyakan muallaf di Jayapura masuk Islam karena motif perkawinan. Hal ini membuat urgennya pembinaan muallaf guna memantapkan akidah keislaman mereka.meski demikian, tak bisa dipungkiri juga ada beberapa muallaf yang masuk Islam karena mendapatkan pencerahan atau karena mendapatkan hidayah lewat mimpi, seperti yang dialami oleh pak Yoris, 72 tahun (penduduk asli Papua), yang mengaku masuk Islam sejak 2 tahun yang lalu karena mendapatkan mimpi. Demikian pula yang dialami oleh Anita, 27 tahun seorang perempuan asal Manado yang masuk Islam karena tertarik dan sering mengikuti pengajian yang dibawakan oleh Ustadz Burhanuddin.

Latar belakang etnik para muallaf juga berbedabeda, hampir setengahnya adalah penduduk asli Papua, sisanya adlah penduduk pendatang dari Manado, Toraja, Maluku, NTT, Batak, Jawa, Tionghoa, dan Bali. Latar belakang agama umumnya adalah Protestan, sebagian kecil berasal dari agam Katolik dan ada beberapa orang yang peneliti dapatkan dari data base berasal dari agama Hindu dan Buddha.

Umumnya (lebih 60\%) muallaf adalah perempuan, bahkan yang aktif dalam kegiatan pembinaan muallaf sebagian besar adalah perempuan. Hal ini dikarenakan, mereka masuk Islam karena faktor perkawninan dan mengikuti agama suami. Latar belakang ekonomi para muallaf dapat dikatakan hampir seluruhnya berlatar ekonomi menengah ke bawah, sehingga pembinaan dalam hal ekonomi juga tak bisa diabaikan.

Untuk muallaf yang berasal dari Pegunungan Tengah Papua, tinggal secara komunal dan membentuk kompleks muallaf di Jalan Muhammad Yamin kompleks Angkasa Pura. Di kompleks tersebut bermukim 12 KK muallaf yang berasal dari Wamena. Saat ini mereka telah memiliki sebuah mushalla yang berada di tengah pemukiman mereka.

\section{Resources Sosial yang Terlibat dalam Proses Pembinaan Muallaf}

Pembinaan muallaf di Kota Jayapura di lakukan oleh individu yang memang berstatus sebagai dai dan umumnya berlatar belakang pegawai Kementerian Agama. Selain pembinaan individu, juga terdapat pembinaan yang dilakukan oleh kelompok, organisasi atau yayasan. Diantara individu yang giat melakukan pembinaan terhadap muallaf adalah Ustadz Burhanuddin, S. Ag, penyuluh agama Islam Kemenag Kota Jayapura. Selain sering melakukan pengislaman, beliau juga terlibat langsung dalam pembinaan muallaf

\footnotetext{
${ }^{12}$ Pernyataan tersebut pertama kali peneliti dengar dari Adnan Yelipele (seorang tokoh pemuda muslim asli papua), dan pernyataan yang sama juga peneliti dengar langsung dari Tony Victor Wanggai (tokoh muslim asli Papua asal Serui), Fadhal Alhamid (anggota dewan adat Papua), Thaha Alhamid (Sekjen Presidium Dewan Papua), H. Wawan Asso dan beberapa muslim asli Papua lainnya.

${ }^{13}$ Data Seksi Urais Kemenag Kota Jayapura 2012.
} 
meski masih belum terstruktur dengan baik. Tokoh lain yang juga giat melakukan pembinaan adalah ustadz Jamal Iribaram yang saat ini menjabat sebagai Kasub Bag TU Kanwil Kemenag Papua. Beliau sejak dekade 1970-an aktif melakukan dakwah Islam, khususnya kepada masyaraat asli Papua. Ustadz Syamsuddin Taliwongso, seorang mantan pendeta yang masuk Islam pun giat melakukan pembinaan muallaf baik secara kolektif maupun secara personal.

Pembinaan muallaf yang dilakukan oleh kelompok, diantaranya Kelompok kajian Muallaf (KKM) yang didirikan oleh Ust. Muhamamd Taufik, S. Ag (penyuluh agama Islam yang sekarang menjabat sebagai kepala KUA Jayapura Selatan. KKM didirikan pada bulan September 2008 dengan tujuan untuk membina muallaf guna memantapkan akidah mereka. Kajian rutin dilaksanakan seminggu sekali tepatnya setiap hari minggu di mesjid al-Askar Jayapura. Pada awal dibentuk, muallaf yang dibina mencapai 120 orang, namun pada perkembangannya, saat ini muallaf yang intensif mengikuti pengajian sekitar 25 orang dan umumnya adalah perempuan. ${ }^{14}$

Forum Komunikasi Muslim Pegunungan Tengah juga aktif melakukan pembinaan muallaf, namun sifatnya tidak secara umum, melainkan personal kepada orang-orang dari pegunungan tengah yang bermukim di Jayapura dan masuk Islam, yang hampir semuanya aadalah karena motif perkawinan. Saat ini, ada 6 muallaf yang dibina oleh FKMPT dan semuanya adalah perempuan. ${ }^{15}$

Untuk Majelis Muslim Papua, pembinaan muallaf diprogramkan sebagai program kerja dalam divisi dakwah, namun hingga saat ini di Jayapura belum bisa dilaksanakan, karena saat ini MMP fokus pada pembenahan dan konsoidasi organisasi. Pembinaan muallaf yang dilakukan oleh MMP dilakukan di kabupaten-kabupaten. ${ }^{16}$ Ormas seperti Muhammadiyah dan Hidayatullah di Jayapura tidak secara langsung membina muaallaf, namun kedua ormas tersebut merekrut anak-anak muallaf dari pegunungan untuk ekmudian mereka bina di pesantren mereka. Sedangkan ormas NU, jug a memprogramkan pembinaan muallaf, namun pada kepengurusan kali ini belum berjalan maksimal." Jamaah tabligh, merupakan gerakan dakwah yang gencar melakukan pembinaan muallaf di daerah pegunungan Papua, namun untuk di Jayapura mereka lebih fokuskan sebagai tempat konsolidasi dakwah mereka untuk wilayah Papua.

Di Kabupaten Jayapura, juga terdapat sebuah Yayasan Pembinaan Muallaf yang didirikan dan dibina langsung oleh Ust Helmi Sulaksono (saat ini menjabat sebagai Kasi Urais dan Haji Kemenag Kabupaten Jayapura. Beliau aktif melakukan pembinaan muallaf sejak tahun 2000 dan hingga saat ini masih intensif melakukan pembinaan dan pengislaman, khsusunya bagi penduduk asli papua yang ebrmukim di sekitar danau Sentani.

\section{Model-model Pembinaan Mullaf}

Sebagaimana telah dipaparkan sebelumnya, pembinaan muallaf di Jayapura dilakukan baik oleh individu maupun lembaga. Terdapat perbedaan model pembinaan yang dilakukan antara keduanya. Pembinaan yang dilakukan oleh individu biasanya lebih bersifat personal dan bimbingan yang diberikan lebih bersifat pribadi. Sedangkan pembinaan yang dilakukan oleh kelompok cenderung lebih sistematis, lebih rutin, dan biasanya diselingi dengan kegiatan-kegiatan kolektif, seperti bakti sosial, dan lain-lain.

Pembinaan yang dilakukan oleh individu, sebagaimana dituturkan oleh ustadz Burhanuddin, S. Ag, pembinaan muallaf yang dilakukannya lebih bersifat personal, insidentil, dan konsultatif. Jika ada yang datang kepada beliau untuk diislamkan, setelah memastikan kesungguhan niat orang tersebut dan kemudian dituntun untuk membaca syahadat, maka beliau langsung memberikan bimbingan tentang dasardasar ajaran dan amaliah Islam secara teori dan praktek. Jika muallaf tersebut adalah perempuan, maka beliau dibantu oleh istri untuk memberikan bimbingan, khususnya bimbingan praktek. Selepas itu, ustadz Burhanuddin senantiasa berusaha membangun komunikasi dan silaturahmi dengan muallaf yang diislamkannya, setidaknya komunikasi via telepon. Tidak ada pengajian rutin yang dibuat oleh ustadz Burhanuddin khusus untuk muallaf. Bimbingan yang dilakukan lebih bersifat personal dan konsultatif dengan muallaf yang dibimbingnya. Biasanya muallaf tersebut yang datang atau menghubungi beliau untuk bertanya atau konsultasi. Konsultasi yang dilakukan seputar amaliah Islam hingga konseling persoalan keluarga.

Wawancara dengan Ustadz Muhammad Taufik di KUA Jayapura Selatan tanggal 11 Juli 2012.

Wawancara dengan Ustadz Adnan Yelipele di rumahnya pada tanggal 11 Juli 2012.

Wawancara dengan Fadhal al-Hamid di sekertariat MMP pada tanggal 14 Juli 2012.

Wawancara dengan ketua PW NU Provinsi Papua, Tony Victor Wanggai, tanggal 10 Juli 2012 di kantor NU Papua. 
Jika ada muallaf yang lama tak menghubungi, beliau sendiri yang biasanya menghubungi atau datang mengunjungi rumah muallaf tersebut. Hal ini dilakukan dalam rangka membuat muallaf tersebut senantiasa merasa dibimbing dan diperhatikan. ${ }^{18}$

Ustadz Syamsuddin Taliwongso yang telah belasan tahun berkiprah dalam dakwah dan pembinaan muallaf di Jayapura sangat proaktif melakukan pembinaan langsung kepada para muallaf bahkan hingga door to door. Ustadz Syansuddin yang mantan pendeta tersebut, biasanya memuai materi bimbingan kepada para muallaf yang sebelumnya beragama Kristen atau Katolik dengan materi-materi kristologi dalam rangka memantapkan keraguan muallaf tersebut pada agamanya yang dulu dan memantapkan keyakinan pada akidah Islam. Ustadz Syamsuddin berkiprah selama belasan tahun secara individu dalam hal pembinaan muallaf, hingga bersama Ustadz Taufik Muhamamd, S. Ag (alumni fakultas Dakwah IAIN Alauddin dan kepala KUA distrik Jayapura Selatan) membentuk Kelompok Kajian Muallaf pada September 2008, dan ustadz Syamsuddin menjadi pembina serta rutin memberikan pengajian setiap hari'ahad di mesjid al-Askar Jayapura. ${ }^{19}$

Salah seorang "pendekar" dakwah yang aktif melakukan pembinaan muallaf pada masyarakat asli Papua, khususnya yang berasal dari pegunungan, adalah ustadz Drs. Jamal Iribaram. Sejak dekade 1970-an beliau terjun langsung melakukan dakwah dan pembinaan muallaf. Pembinaan yang beliau lakukan adalah dengan berbaur langsung dengan mereka dan mengajarkan Islam. Strategi yang beliau lakukan juga adalah dengan mencarikan bantuan sekolah bagi anak-anak Papua muallaf, khususnya di sekolah-sekolah Islam, baik yang dikelola oleh Yapis, Muhammadiyah, maupunHidayatullah di sekitar Jayapra. Aspek-aspek Islam yang paling pokok beliau tekankan pada para muallaf adalah ajaran Islam tentang pendidikan dan hidup sehat dan bersih. Strategi dakwah yang dilakukan pun bersifat persuasif dan moderat, khususnya terkait dengan kultur masyarakat Papua yang sulit dilepaskan dari binatang babi. ${ }^{20}$

Selain pembinaan yang dilakukan oleh individu, pembinaan muallaf secara lebih terorganisir dilakukan oleh majelis taklim, organisasi, dan yayasani. Setidaknya ada tiga kelompok atau organisasi yang intens melakukan pembinaan muallaf di Jayapura, dari majelis taklim ialah Kelompok kajian Mualalf yang didirikan oleh ustadz Taufik Muhamamd, S. Ag, yang intens melakukan pembinaan sejak tahun 2008. Pembinaan yang dilakukan oleh ormas adalah pembinaan yang dilakukan oleh Forum Komuniaksi Muslim Pegunungan Tengah (FKMPT), yang sebelumnya bernama Forum Komunikasi Muslim Jayawijaya (FKMJ) Papua yang diketuai oleh bapak Ismail Asso, aktif melakukan pembinaan muallaf, khususnya dari kalangan pribumi pegunungan Jayawijaya Papua sejak didirikannya pada tanggal 3 Maret 2003. ${ }^{21}$ Selain itu di Sentani terdapat yasayan khusus bergerak pada dakwah dan pembinaan muallaf yang didirikan oleh ustadz Helmi Sulaksono pada bulan Mei tahun 2000 dan disahkan oleh akta notaris Theresia Pontoh, SH di tahun yang sama. ${ }^{22}$

Kelompok Kajian Muallaf (KKM) yang didirikan dalam rangka mengorganisir pembinaan muallaf, khususnya yang diislamkan di KUA Jayapura Selatan seama 4 tahun ini inetnsif melakukan program pembinaan, baik berupa pengajian rutin yang dilakukan setiap ahad pagi di mesjid al-Askar Jayapura, pembinaan yang bersifat personal atau door to door, peringatan hari-hari besar Islam, hingga program-program pembinaan berupa kegiatan sosial yang melibatkan para muallaf yang dibina. Materi-materi pengajian yang diberikan, khususnya bagi para muallaf baru adalah materi seputar kristologi lalu dilanjutkan dengan materi akidah Islam, selanjutnya materi-materi seputar praktek ibadah dan bimbingan baca tulis Alquran, serta materi seputar muamalh dan akhlak Islam. Pendekatan personal door to door dilakukan bagi jamaah muallaf yang baru serta muallaf yang telah jarang mengikuti pengajian rutin. Bantuan material juga biasa diberikan kepada para muallaf yang mengalami kesulitan ekonomi. Peringatan hari-hari besar Islam juga terprogramkan secara rutin, baik berupa acara yang bersifat seremonial maupun kegiatan sosial. Seperti saat menjelang Ramadhan yang lalu, jemaah KKM melakukan bakti sosial ke salah satu panti asuhan di Sentani. ${ }^{23}$

\footnotetext{
${ }^{\text {is }}$ Wawancara dengan ustadz Burhanuddin di rumahnya pada tanggal 15 Juli 2012.

"Wawancara dengan ustadz Muhammad Taufik

20 Wawancara dengan bapak jamal Iribaram di kanwil kemenag Papua tanggal 11 Juli 2012.

${ }^{21}$ Wawancara dengan Asri Ramadhan yelipele tanggal 17 juli 2012 di mushalla FKMPT.

${ }^{22}$ Wawancara dengan bapak Helmi Sulaksono tanggal 11 Juli 2012 di kantor yayasan al-Muhtadin Sentani

${ }^{23}$ Wawancara dengan ustadz Muhamamd Taufik
} 
Forum Komunikasi Muslim Pegunungan Tengah (FKMPT) Papua, intensif melakaukan pembinaan terhadap warganya degan pola pembinaan yang lebih mengarah pada peningkatan tingkat pendidikan anakanak muallaf serta bimbingan seputar pola hidup bersih dan sehat menurut tuntunan Islam. Pola pembinaan tidak berupa pengajian rutin, melainkan setiap tahunnya mengirim anak-anak Papua baik yang orang tuanya muallaf atau tidak untuk disekolahkan pada pesantrenpesantren di Jawa, diantaranya pesantren DarunNajah Jakarta. Dengan pola ini diharapkan dapat meningkatkan kualitas pemahaman keagamaan generasi muda muslim Papua. Model pembinaan muallaf yang dilakukan oleh FKMPT juga dengan membentuk kompleks pemukiman muallaf di Jalan Muhammad Yamin kompleks Angkasa Jayapura. Pembentukan kompleks muallaf ini dilakukan dalam rangka membangun saling kebersamaan dan kekeluargaan serta saling menguatkan sesama muslim asli Papua. ${ }^{24}$

Yayasan al-Muhtadin Sentani, merupakan lembaga pembina muallaf yang dalam pandangan peneliti adalah yang paling mapan dan paling terstruktur. Didirikan oleh ustadz Helmi Sulaksono, S. Ag (saat ini menjabat Kasi Urais Kemenag Kab Jayapura dan mantan ketua PD Muhammadiyah Kab Jayapura), sejak tahun 2000, yayasan ini fokus pada pembinaan muallafdi daerah Sentani dan sekitarnya. Berdasarkan data base yayasan, telah 297 muallaf yang diislamkan dan dibina oleh yayasan ini. Pola pembinaan yang dilakukan selain pengajian rutin yang dilaksanakan setiap rabu pagi di sekertariat yayasan juga dengan membentuk kelompok qasidah yang anggotanya adalah para muallaf. Latihan qsidah dan qira'ah biasanya dilakukan setiap ahad pagi, terkhusus qasidah biasanya latihan diintensifkan menjelang peringatan hari besar Islam atau momentum-momentum tertentu, seperti perlombaan dan festival. ${ }^{25}$

Saat ini ada 11 ustadz dan ustadzah yang intensif melakukan pembinaan di yayasan alMuhtadin dengan spesifikasi materi masingmasing. ${ }^{26}$ Adapun ustadz dan spesifikasi materi binaannya adalah:

\begin{tabular}{|c|l|c|c|c|}
\hline No & \multicolumn{1}{|c|}{ Nama } & Pekerjaan & Pendidikan & Materi \\
\hline I & Helnii Sulaksono & PNS & SI & Tarikh Islam \\
\hline 2 & Dwi Budi Nugroho & PNS & D3 & Akhlak \\
\hline 3 & Siswoyo & TNI AU & PGA & Akhlak dan Qira 'ah \\
\hline $\mathbf{4}$ & A. Afiandi & TNI AD & PGA & Akidah islam \\
\hline 5 & Komari & TNI AD & PGA & Hadis dan Qasidah \\
\hline $\mathbf{6}$ & Nikmatussolihah & Guru & S] & Iqra dan Qasidah \\
\hline 7 & Siami, S. As & Guru & SI & Iqradan Qasidah \\
\hline$\%$ & H). Mugiyati & Swasta & SMA & Qasidah \\
\hline 9 & Syahroni & Swasta & Pesantren & Ibadah/Fiqh \\
\hline 10 & Damsiri & Swasta & Pesantren & Tajwid/0/ra 'ah \\
\hline 11 & Makmun Rosidi & PNS & SI & Akidah Islam \\
\hline
\end{tabular}

Sumber: Data Yayasan al-Muhtadin Sentani

Pembinaan lainnya yang dilakukan adalah dengan intensif mengunjungi jamaah muallaf yangtinggal jauh dari kota Sentani bahkan yang bermukim di pulau-pulau di danau Sentani atau yang tinggal di pedalaman sekaligus memberikan santunan berupa sedekah dan zakat kepada mereka. Latar belakang jamaah yang umumnya ekonomi lemah dan tinggal jauh dari Sentani, membuat pengurus yayasan memberikan uang transpor sebesar Rp. 25.000 setiap jamaah datang pengajian. Yayasan ini juga telah memiliki aset berupa sekertariat tetap berupa sebuah ruko di Sentani kota yang merupakan hasil wakaf dari seorang donatur serta sebuah mobil L 300 yang juga pemberian seorang donatur dari Jakarta dan difungsikan sebagai mobil angkutan umum guna menunjang operasional yayasan. ${ }^{27}$

\section{Problematika Pembinaan Muallaf}

Untuk kasus Jayapura, pembinaan muallaf menemui beberapa problem yang cukup menghalangi maksimalisasi pembinaan para muallaf. Kendala tersebut mencakup kendala sosial-politik, kultural, geografis hingga ekonomi, danproblem kebijakan struktural.

\section{a. Isu Islamisasi}

Program pembinaan muallaf di Papua pada umumnya, dan Jayapura pada khususnya, merupakan hal yang sedikit menuai resistensi. Oleh sebagian kalangan di Papua, pembinaan muallaf identik dengan pengislaman atau Islamisasi dan hal ini dianggap sebagai ancaman bagi eksistensi identitas ke-Papuaan mereka. Islam identik dengan pendatang, Islam identik dengan NKRI (bagi sebagian orang-orang Papua yang pro kemerdekaan) ${ }^{28}$ Oleh karena itu, pro-

\footnotetext{
${ }^{14}$ Wawancara dengan ustadz Adrian Yelipele

:s Wawancara dengan ustadz Helmi Sulaksono.

${ }^{16}$ Data diambil dari papan potensi yang terdapat di kantor yayasan al-Muhtadin Sentani.

" Wawancara dengan ustadz Helmi Sulaksono.

:s Wawancara dengan Reza Fauzan al-Hamid di rumahnya pada tanggal 19 Juli 2012.
} 
gram pembinaan muallaf perlu kehati-hatian agar tidak menuai kesalahpahaman dan konflik sosial.

Ketakutan akan isu Islamisasi yang membayangbayangi program pembinaan muallaf, tampaknya menjadi kendala yang membuat program pembinaan kerap berjalan tidak maksimal. Hal ini yang peneliti temui ketika menemui beberapa informan untuk melakukan wawancara, mereka penuh kewaspadaan dan awalnya sangat berhati-hati. Beberapa kali terjadi gangguan dan teror yang diterima oleh beberapa pembina, seperti dituturkan oleh ustadz Helmi Sulaksono, beberapa kali dalam pengajiannya di yayasan al-Muhtadin diteror oleh orang-orang tertentu. Kehati-hatian terhadap isu Islamisasi ini yang membuat beberapa pengurus ormas Islam tidak memprogramkan pembinaan muallaf yang jelas-jelas sangat urgen dalam rangka peningkatan kualitas kehidupan keagamaan para muallaf. Sebagaimana dituturkan oleh Dr. Tony Wanggai, yang menjabat sebagai ketua umum P W NU Papua, NU belum bisa menjalankan program pembinaan muallaf karena kendala tersebut. Hal yang sama juga diakui oleh Fadhal al-Hamid, salah seorang pengurus Majelis Muslim Papua (MMP).

Oleh sebagian kalangan Kristen ekstrem di Papua, menganggap adanya upaya Islamisasi di tanah Papua melalui program transmigrasi, dan banyaknya migrasi pendatang muslim masuk ke Papua serta melalui dakwah Islam di kalangan penduduk asli Papua. Hal ini tidak hanya menjadi kendala bagi program pembinaan muallaf, tapi juga sangat rentan menimbulkan konflik sosial berlatar belakang agama. Menjelang Ramadhan 2011, konflik tersebut hampir terjadi ketika seorang muazin dibunuh ketika saat mengumandangkan azan subuh, serta seorang mahasiswa STAIN al-Fatah yang dipanah ketika melakukan wudhu untuk shalat subuh. Untungnya kasus ini dapat dilokalisir dan diredam, walau sampai ini belum terusut tuntas, hingga kasus tersebut tidak meluas menjadi konflik sosial. ${ }^{29}$

\section{b. Benturan kultural}

Benturan kultural antara budaya lokal dan ajaran Islam juga menjadi kendala dalam pembinaan. Budaya Papua yang menjadikan babi sebagai binatang "istimewa" dalam kehidupan sosial maupun ekonomi berbenturan dengan ajaran Islam yang mengharamkan babi. Kendala ini diakui oleh ustadz Jamal Iribaram yang aktif melakukan dakwah Islam di kalangan masyarakat asli Papua, hal yang senada juga diakui oleh beberapa pengurus FKMPT yang peneliti temui.Babi menjadi binatang istimewa karena menjadi indikator strata sosial, menjadi mahar perkawinan, aset ekonomi yang bernilai tinggi, serta menjadi bagian penting dalam upacara-upacara adat. ${ }^{30}$

Pembinaan muallaf yang dilakukan tentu tak bisa secara frontal, para dai akhirnya untuk sementara "harus berkompromi" dengan tidak langsung menegaskan keharaman dan kenajisan babi. Butuh proses dan waktu yang lama untuk membuat mereka menerima keharaman dan kenajisan babi. Kalau pun mereka akhirnya sudah tidak makan babi, tapi mereka tetap memelihara babi, untuk persiapan mahar perkawinan anak-anak mereka atau sebagai simbol status sosial. Sehingga tak heran jika masih ditemui warga Papua yang sudah lama memeluk Islam tapi masih memelihara babi.

\section{c. Kurangnya tenaga penyuluh agama Islam yang berstatus PNS}

Kendala yang bersifat teknis adalah kurangnya tenaga penyuluh agama Islam yang berstatus PNS. Untuk lingkungan kenenterian agama kota Jayapura dan kabupaten Jayapura masing-masing hanya tersedia 2 penyuluh agama Islam yang berstatus PNS. Hal ini menjadi kendala dalam maksimalisasi program pembinaan muallaf, karena umumnya adalah tenaga sukarela yang melakukan pembinaan semata karena idealisme dakwah.

\section{d. Kendala geografis}

Kondisi geografis yang berbukit-bukit dan wilayah yang luas hingga sampai perbatasan Papua Nugini serta masih banyaknya masyarakat yang bermukim di daerah yang agak sulit diakses termasuk tinggal di pulau-pulau di danau Sentani membuat akses dakwah dan pembinaan menjadi tidak maksimal. Kendala jarak dan kesulitan akses ini yang kerap menjadi alasan beberapa muallaf yang jarang hadir dipengajian. Faktor ini pula yang membuat yayasan al-Muhtadin memberikan uang transpor Rp. 25.000 kepada setiap muallaf yang datang ke pengajian. Beberapa muallaf yang tinggal di perkampungan pada pulau-pulau di danau Sentani membuat kesulitan untuk dibina secara intensif.

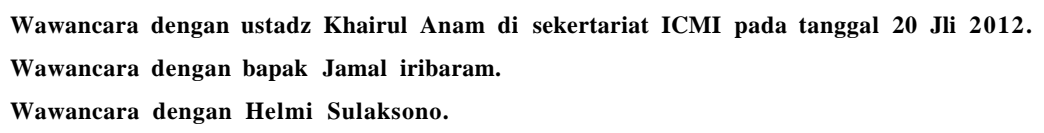




\section{e. Kendala pendanaan}

Finansial juga menjadi persoalan yang membuat pembinaan muallaf menjadi kurang maksimal. Latar belakang para muallaf yang umumnya adalah ekonomi lemah, membuat pembinaan muallaf harus juga memperhatikan aspek penguatan ekonomi muallaf. Pendanaan program pembinaan lebih banyak mengandalkan donatur individual, bahkan harus merogoh dari kocek pembina sendiri. Hal ini diakui oleh ustadz Burhanuddin dan ustadz Muhammad Taufik selaku pembina muallaf. Pembinaan muallaf lebih bermodalkan pada idealisme dan tanggung jawab dakwah para pembina meski harus merogoh kocek sendiri untuk pendanaan.

\section{Dukungan Kementerian Agama}

Sebagaimana penjelasan di atas, program pembinaan muallaf di Jayapura banyak diinisiasi dan dijalankan oleh person-person pegawai dan pejabat kementerian agama, khususnya penyuluh, KUA, bidang penamas, dan seksi urais kemenag. Meskipun berlatar belakang pegawai dan pejabat kementerian agama, pelaksanaan program pembinaan tidak mengatasnamakan program kemenag secara resmi. Melainkan, dengan memanfaatkanjabatan, tugas, dan kewenangan masing-masing sebagai orang kementerian agama.

Tanggung jawab sebagai penyuluh, personil KUA, maupun pejabat di bidang penamas dan urais kemenag serta tugas dan wewenang dimanfaatkan untuk membuka jaringan dan program pembinaan. Seperti yang dilakukan ustadz Muhammad Taufik, S. Ag selaku kepala KUA distrik Jayapura Selatan, membentuk majelis taklim khusus untuk muallaf dengan nama Kelompok Kajian Muallaf, yang para muallaf binaannya berasal dari orang-orang yang diislamkan di KUA-nya. Demikian pula pembinaan yang dijalankan oleh beberapa personil kemanag yang lain baik pegawai fungsional penyuluh dan guru agama maupun pejabat struktural seperti ustadz Helmi Sulaksono selaku kasi urais Kemanag Kabuapten Jayapura.

Tidak terprogramkannya secara khusus pembinaan muallaf dalam program kerja kementerian agama, diakui oleh H. Wawan Asso selaku kabid penamas kanwil kemenag Papua, selain karena tidak adanya tanggung jawab khusus pembinaan muallaf kepada kemeneterian agama. Yang lebih penting lagi untuk menghindari isu atau stigma Islamisasi yang melibatkan kementerian agama secara institusional, dan hal ini sangat sensitif. Sehingga pembinaan muallaf pun dijalankan secara personal atas inisiatif dan kreatifitas personil kemenag yang memang bertugas dalam hal pembinaan umat.

\section{PENUTUP}

\section{Kesimpulan}

Program pembinaan muallaf di Jayapufa dilakukan oleh institusi maupun secara personal oleh dai yang juga berlatar belakang pegawai atau pejabat kementerian agama. Sedangkan pembinaan yang dilakukan oleh institusi oleh majelis taklim yang diberituk khusus untuk membina muallaf, yaitu Kelompok Kajian Muallaf (KKM) yang dibidani oleh kepala KUA Jayapura Selatan, ormas Islam yaitu Forum Komunikasi Muslim Pegunungan Tengah (FKMPT) Papua yang khusus membina muallaf pribumi asli Papua dari pegunungan Jayawijaya dan sekitarnya, serta di Sentani terdapat yayasan yang fokusnya pada pembinaan muallaf, yaitu yayasan al-Muhtadin yang dibina oleh kasi urais kemenag kabupaten Jayapura. Terdapat perbedaan model pembinaan yang dilakukan antara yang dilakukan secara personal maupun lembaga. Pembinaan yang dilakukan oleh individu biasanya lebih bersifat personal dan bimbingan yang diberikan lebih bersifat pribadi. Sedangkan pembinaan yang dilakukan oleh kelompok cenderung lebih sistematis, lebih rutin, dengan kegiatan yang terprogram. seperti pengajian rutin, bimbingan baca tulis Quran, peringatan hari besar Islam bakti sosial, dan lain-lain.

Program pembinaan muallaf menghadapi beberapa kendala dan problem, yang mencakup kendala sosial-politik, kultural-, geografis hingga ekonomi, dan problem kebijakan struktural. Isu islamisasi yang sangat sensitif, benturan kultural, faktor geografis, pendanaan, hingga kebijakan struktural terkait minimnya tenaga penyuluh agama Islam yang tersedia menjadi kendala maksimalisasi pembinaan muallaf di Jayapura.

Program pembinaan muallaf mendapatkan dukungan bahkan inisiasi langsung dari person-person kementerian agama yang tugas dan kewenangannya terkait pembinaan umat. Meski kementerian agama secara institusional tidak terlibat langsung dalam program pembinaan. Namun, keberadaan person-person pegawai dan pejabat kemenag yang terlibat aktif sudah cukup menggambarkan dukungan kementerian agama terhadap pembinaan muallaf di Jayapura. 